\title{
The Role of Competition Advocacy: The Serbian Experience
}

\author{
Ivana Rakić
}

\section{Introduction}

As a young competition authority, the Serbian Commission for the Protection of Competition (hereafter, Commission) is buildings up its capacity with the primary goal to effectively and consistently enforcing competition rules. The use of this broad and undoubtedly important "traditional" tool for promotion of a competitive market and thereby protection of competition and consumer welfare has been the first duty of the Commission since its establishment in 2005 . $^{1}$

Although the Commission remains committed to the systematic enforcement of the competition rules, enforcement is not the only way and not always the most effective tool to encourage greater competition. The Commission very early on recognised the need to do more than simply enforce competition law and to take into account the other segments of competition policy for which substantial resources should be allocated. Therefore, competition advocacy was included in Serbian competition policy and the Commission proceeded to perform this additional function, allowing it to influence all the policies that affect competition in the national market.

During a period of only 12 years, competition advocacy became a very important segment of Serbian competition policy and a complement to the Commission's

\footnotetext{
The findings, interpretations, and conclusions expressed in this paper are those of the author and do not necessarily reflect the views of the Commission for the Protection of Competition of Republic of Serbia.

${ }^{1}$ The Law on the Protection of Competition $(2009,2013)$ regulates the protection of competition in the market of the Republic of Serbia, in order to achieve economic prosperity and social well-being, and especially the benefits of the consumers (Article 1).

I. Rakić

Commission for the Protection of Competition of the Republic of Serbia, Belgrade, Serbia

Institute of Comparative Law, Belgrade, Serbia

e-mail: ivana.rakic@kzk.gov.rs
} 
enforcement activities, although it substituted competition enforcement on several occasions. ${ }^{2}$ The Commission's proactive activities were focused on the development of a competition culture and promotion of an open, competitive market. Its approach stems from the transformational processes in the Serbian economy, especially its ongoing fundamental changes.

Considering the importance of competition advocacy in developing and transition countries, such as Serbia, the aim of this article is to provide a short review and analysis of the stipulations of the Law on the Protection of Competition related to the competencies of the Commission in the field of advocacy, and to give a de lege lata overview of several examples from the Commission's practice.

Section 2 of this paper examines the definition of competition advocacy and the significance of this advocacy in Serbia and other developing and/or transition countries, as well as certain prerequisites for effective advocacy by competition authorities. Section 3 is related to the Serbian legal framework for competition advocacy. Section 4 focuses on the most successful examples and highlights Serbian experience and some realised cases of advocacy initiatives. The material in this section is organised into several parts in order to include the large number of activities that should be classified as forms of competition advocacy (giving opinions, cooperation with other state authorities, i.e. independent sector regulators, the use of market studies, etc.). The Conclusion is the last part of the paper, which includes final remarks and recommendations for the Serbian Commission and policy makers.

\section{The Definition and Importance of Competition Advocacy}

According to the widely accepted definition of competition advocacy advanced by the International Competition Network, competition advocacy refers to "those activities conducted by the competition authority related to the promotion of a competitive environment for economic activities by means of non-enforcement mechanisms, mainly through its relationships with other governmental entities and by increasing public awareness of the benefits of competition" (ICN 2002). By explaining that there are two parts of the definition, the ICN refers to both the ends and the means of competition advocacy.

The first part of this definition defines competition advocacy in terms of what it is not and refers to almost all activities of the competition authority that do not fall under the enforcement category. The second part of the definition identifies the two main branches of competition advocacy: (1) initiatives undertaken by the competition authority towards other public entities in order to influence the regulatory framework and its implementation, and (2) activities by competition authorities

\footnotetext{
${ }^{2}$ For some examples of competition advocacy as a substitute for competition law enforcement in the Republic of Serbia, see Popovic (2013).
} 
aimed at raising the awareness of economic agents, public authorities and the general public about the benefits of competition to the society as a whole and about the role competition policy can play to promote and protect competition (ICN 2002).

Therefore, the competition authority can use its formal powers to influence actors with rule-making powers (government, legislature, and other public authorities) in order to persuade them not to adopt unnecessarily anticompetitive measures or help them to delineate the boundaries of business regulation by adapting regulations and policies which unnecessarily restrict competition in the market. This means that competition authorities must act proactively to help the government to eliminate barriers to competition and to bring about public policies that lower barriers to entry, promote deregulation and trade liberalisation, and otherwise minimise unnecessary government intervention in the marketplace (Shyam Khemani et al. 1999).

To address the problems of government-created barriers to competition, the competition authorities analyse and advocate for policies that promote and protect competition by providing methods for identifying unnecessary restraints on market activities and by developing alternative, less restrictive regulatory approaches that can achieve the same goals, but at a lower cost than the competitive process. For this reason, competition advocacy becomes a more effective segment of competition policy than legislation enforcement, since the latter is inevitable and very resources consuming, i.e. it inevitably creates a huge administrative burden on the competition authority and other institutions (Begović et al. 2003).

That is why competition advocacy represents a soft power in promoting competition and liberalisation measures to improve the performance of market-based economies. Having in mind its objective, "the promotion of a competitive environment for economic activities", replacing (or avoiding) regulations with greater anticompetitive effects by government measures with less adverse consequences appears to be one operational way of interpreting this objective of competition advocacy (Evenett 2006).

Hence, the need for appropriate competition advocacy appears to be quite clear in developing and transition countries as their economic policies are undergoing fundamental market driven changes: markets in these countries are becoming more open; new government and regulatory institutions are being formed; foreign trade is assuming greater influence; and state owned enterprises are being privatised (Clark 2005). Furthermore, it is considered that competition advocacy by competition authorities in the EU candidate countries, like in Serbia, is extremely important.

Some of the existing reports on competition advocacy believe that competition authorities should give priority to advocacy activities over enforcement of competition law in developing and transition countries (Evenett 2006), although these activities unite under a single banner: promoting efficiency (Stucke 2008). ICN Report on Advocacy and Competition Policy pointed out that the rationale for prioritising competition advocacy over enforcement activities in these countries could be explained with three reasons (ICN 2002, 2004). ${ }^{3}$ First, in developing and

\footnotetext{
${ }^{3}$ See also Kovacic (1997) and Rodriguez and Coate (1997).
} 
transition countries, the spread of market reform (caused, for example, by privatisation) has given rise to an intensive rule making process and dialogue between the competition authority and the rule makers at an early stage may ensure that competition provides the foundation for legislation. A second reason is that these countries have undergone a substantial liberalisation which has triggered the activity of interest groups lobbying with public authorities for lost privileges. Therefore, competition authorities are trying to instil competitive values in sectorspecific regulation through advocacy, and to reduce the possibility of regulatory capture by interest groups. According to the third reason, competition law enforcement requires sophisticated adjudication, with which young competition authorities and judicial systems have little experience.

All these rationales are important for Serbia, but it appears that the first is particularly important in regulated sectors, since the country is moving from the domination of state-owned enterprises towards a more competitive market structure and advocacy can enhance understanding competitive market forces. Free and undistorted competition and a market without considerable barriers to entry are key remedies for the Serbian economy, which has been plagued for decades by challenges that can arise in a small market economy within a specific political and international relations framework.

In this context, the advocacy efforts of the Commission could promote new ideas of competition protection among businessmen, lawyers, politicians and economic policymakers, and at the same time influence other public policies that create non-competitive market structures and behaviour (for example, foreign trade policies, privatisation and restructuring policies, various public policies that affect barriers to entry for new firms, etc.). Therefore, the accepted meaning in Serbia could be "promoting a competitive environment", which seems to suggest that the government measures are broader than those that promote entry into markets (Evenett 2006).

As many studies based on the best practices of developing and transition countries have already shown, young competition authorities should confine themselves to advocacy during the early implementation stages of competition policy and only gradually introduce enforcement of competition law (ICN 2002). Advocacy is most effective in the phase of the "consolidation" of competition culture, and it is more effective than legislation enforcement under these circumstances. A variety of arguments have been brought up in support of this viewpoint (ICN 2002).

Several other differences that affect competition advocacy exist between developed countries, on one hand, and developing and transition countries on the other. For example, in developing and transition countries market institutions are much weaker and less effective, the transparency of procedures and the accountability of public authorities is usually lower, and there are severe limitations upon the availability of the resources necessary to set up an efficient competition authority, especially in the smaller countries (ICN 2002).

All these circumstances lead to the conclusion that an effective competition advocacy in developing and transition countries requires certain essential conditions, i.e. prerequisites that represent challenges to most young competition authorities. In 
the first place, the competition authority should have a significant degree of independence from political influence from both inside and outside the government. Furthermore, it should have sufficient resources to support both its enforcement and advocacy functions. It is also important to acquire credibility and extend it throughout the public and private sectors, to policymakers and their constituents-businesses, workers and consumers (Clark 2005).

For Serbia, in this context it is also important to create public awareness which would include dissemination of information on competition law to enterprises, particularly widespread adoption of knowledge about the effects of non-competitive market structures and behaviour. However, the Commission should be aware that it might take a long time for such efforts pay off, thereby it should continue its competition advocacy efforts.

\section{Competencies of the Serbian Commission}

Competition advocacy often targets state-owned enterprises sheltered from the competitive process, including railroads, mail, telecommunications and energy, as well as other state institutions, such as the courts, administrative agencies, and legislatures (Stucke 2008). Serbian targeting activities should be similar and focused on legislation, government policy and regulatory reform in the most significant areas that may benefit from competition advocacy, such as foreign trade liberalisation, economic deregulation, state aid, state-owned enterprises, operation of local authorities, privatisation, building a competition culture, etc. ${ }^{4}$

In brief, the opportunities for competition advocacy in Serbia are numerous but the Commission should stay focused on reviewing inadequate regulatory regimes and existing or proposed regulations enforced by sectoral regulators. However, the variety of advocacy instruments suggests that there is no one best advocacy technique to create a competitive environment and improve the overall quality of legislation.

An important advantage of the Serbian competition advocacy is the possibility to use a wide array of advocacy tools and methods to create a competitive environment and influence policymakers, provided by the Law on the Protection of Competition.

In line with the Article 21 of the Law, the Commission is authorised to:

- take part in the preparation of regulations enacted in the field of protection of competition;

- propose to the Government passing regulations pertaining to the implementation of the Law;

- issue instructions and guidelines for implementation of the Law;

- monitor and analyse competition conditions in individual markets and sectors;

\footnotetext{
${ }^{4}$ For more information on policy areas in which competition advocacy in developing and transition countries can be most important, see Shyam Khemani et al. (1999) and Clark (2005).
} 
- give opinions to competent authorities on draft regulations, as well as on current regulations that have an impact on market competition;

- give opinions regarding implementation of regulations in the field of protection of competition;

- establish international cooperation in the field of protection of competition, for the purpose fulfilling international obligations in this area, and collect information on the protection of competition in other countries;

- cooperate with national, provincial and local authorities in order to ensure implementation of the Law and other regulations that regulate issues of importance to the protection of competition; and

- undertake activities to raise awareness on the need to protect competition.

Stemming from the Commission's competencies, as stipulated in Article 21 of the Law, the most important tools for implementing advocacy policies in its practice are: providing opinions on the drafts laws and laws proposals and on current regulations affecting competition policy; conducting sectoral inquiries; enabling direct education via conferences, seminars and workshops; participating in roundtables and conferences; publishing brochures and specialised publications; campaigning; issuing public statements and media interviews with Commission, etc. ${ }^{5}$

The Commission can thus exercise competition advocacy through assessment of the compliance of draft legal acts and legal acts in force with the principles of the competitive environment for economic activities, as well as through proposals to competent state authorities to revise their restrictive acts. Opportunities for discovering advocacy are numerous: government and ministries can consult the Commission before issuing laws or regulations (based on prior working relationships or prior considerations of competition issues or particular concerns); the Commission can undertake competition screening of legislation or legislative proposals on its own initiative, as part of conducting enforcement activities or investigating individual markets/sectors, or based on information from third parties, etc.

In general, these competencies are in line with the best comparative practice which shows an expansion of advocacy tools and methods. Competition authorities worldwide are engaged in policy review in many different ways, based on both explicit (statutory) and implied (informal) grounds (Dabbah 2010). In some jurisdictions, competition authorities enjoy a certain mandate to submit their views on specific matters to the relevant ministry or regulatory agency or other public bodies, but in other jurisdictions, there are no explicit rules on the role of the competition authority under such circumstances (Dabbah 2010). Competition authorities should in any case carefully consider the most appropriate action for a particular situation and be actively involved in legislative affairs.

\footnotetext{
${ }^{5}$ See http://www.kzk.gov.rs/en/medunarodne-i-domace-aktivnosti/domaca-saradnja, last visited 14 August, 2017. For further information on competition policy in Serbia, see Rakić (2009, 2012, 2014).
} 


\section{Serbian Experience}

Since the establishment of the Commission, it has been engaged in a large number of wide-ranging advocacy activities, considered to be particularly necessary for the promotion of a competitive environment for economic activities. The most relevant and demanding task has been addressing laws and regulations in order to eliminate unnecessary restraints on competition, which could be considered as advocacy in the narrow sense of the term.

In the coming years, as the Commission becomes more experienced in competition advocacy activities, it could be expected that the Commission's advocacy practice will increase further, along with the first assessments of its achievements, since it is gradually becoming well-established.

The following examples were selected from the Commission's relatively developed practice of competition assessment of laws and regulations, with aim of pointing out parts of the Serbian competition advocacy program that were successfully carried out and other parts that require a more active approach.

\subsection{Non-binding Opinions}

In the area of competition impact assessment, the Commission is authorised to give opinions to competent authorities on draft regulations, as well as on current regulations that have an impact on market competition. It can carry out such assessments at the request of the relevant state authorities, on its own initiative, or based on information from third parties.

According to information on the Commission's website and in the Commission's annual reports, during the 2006-2016 the Commission issued and submitted 55 opinions to the competent public authorities. ${ }^{6}$ The assessments mostly focused on mapping administrative authorization proceedings and granting exclusive rights that may result in barriers to entry, as well as evaluating other restrictions with regard to market access.

In Serbia, as well as in other countries, the advocacy opinions are not binding for the competent state authorities, including regulators. Moreover, competent state authorities are not obliged to explain the reasons for their decisions if they diverge from the Commission's opinions, although in practice they usually provide an explanation. The law allows them to decide whether to conform to the Commission's opinions or not, or to conform to it only to a certain extent. The possibility of issuing binding opinions would be an effective way of extending influence, but it would also

\footnotetext{
${ }^{6}$ See the Commission's opinions at http://www.kzk.gov.rs/misljenja-na-predloge-propisa-i-navazece-propise-koji-imaju-uticaj-na-konkurenciju-na-trzistu and http://www.kzk.gov.rs/ostalamisljenja, as well as Commission's annual reports, available at http://www.kzk.gov.rs/izvestaji, last visited 14 August, 2017.
} 
effectively create veto power and introduce distinctive incentives to the Commission and legislator, which could have adverse effects. At the same time, the law does not provide a basis for such binding opinions.

Therefore, the success of this advocacy activity depends on the Commission's ability to influence relevant authorities whether its opinions are considered in the regulation and policy making activity of the authority concerned, or to ensure sufficient political support. At any rate, the Commission should be able to assess legislation before it is introduced because policymakers are then more likely to conform, and ex post assessment, i.e., reviewing existing laws, is less effective than reviewing draft legislation.

In line with certain recommendations, it is necessary to adopt explicit rules governing state authorities, in order to mandate effects on competition, or the opinions of the competition authority, must be taken into account when designing regulations and associated policies. Without such rules some state authorities may argue that the competition authority is requiring them to take into account factors that are not part of their legal mandates. Failure to provide such rules may thus narrow the scope of the competition advocacy function (Evenett 2006).

For this reason, an initiative was sent to the Government of the Republic of Serbia to amend its Rules of Procedure, requiring the submission of proposals to the Commission for assessment. However, there has been no response regarding the issue and the Commission's opinions still have no binding force. Nevertheless, the Commission has continued issuing and publishing opinions on regulations, either upon request, or on its own initiative. ${ }^{7}$

Future reform of the Law on the Protection of Competition could introduce the requirement for government departments to seek the opinion of the Commission when introducing restrictions on access to economic activity, or to consider some of the solutions addressing this issue, as stipulated in comparative law. For example, when Italian competition law was amended and advocacy powers were strengthened, the Italian Competition Authority (ICA) got a new competency (according to Art. 21 bis of law 287/1990) to challenge, before the Administrative Courts, legal and administrative acts adopted by public administrations, which have not complied with the Authority's previous (and mandatory) opinions stating that the given administrative act, in the ICA's opinion, is in violation of competition law and principles (Rebecchini 2014; Carpagnano 2016). After this amendment to the law, the effectiveness of such advocacy interventions in Italian practice became significant (Rebecchini 2014).

In the meanwhile, the Serbian Commission has to use persuasion, rather than coercion, to provide political support and convince the government to pursue policies that further competition and enhances consumer welfare and choice. One

\footnotetext{
${ }^{7}$ See Commission for Protection of Competition (2012), Annual Report for 2011, available at http:// www.kzk.gov.rs/kzk/wp-content/uploads/2012/08/Annual-Report_2011.pdf, last visited 14 August, 2017, p. 59.
} 
such situation followed the adoption of the Law on Amendments to the Law on Public Utilities.

The Commission issued the Opinion on the Draft Law on Amendments to the Law on Public Utilities, at the request of the Ministry of Construction, Transport and Infrastructure. ${ }^{8}$ The Commission had previously reacted on several occasions, in its written communications addressed to the Ministry, with regard to the Law that was currently in force, as well as the Draft Law. The Commission stressed the importance of providing equal conditions for all participants in the public utilities market, and in this context drew attention to the negative effects of the creation of a statutory monopoly. It expressed concern that the Ministry opted for solutions that would further limit the potential for competition in the public utilities market and noted that only competition between competitors, through quality and price, can lead to economic progress and well-being of society, especially the benefit of consumers. ${ }^{9}$

The Ministry eventually accepted the comments and suggestions of the Commission, expressed in the Opinion and changed the Draft Law. The Opinion pointed out the provisions stipulating that the Chamber of Commerce and Industry of Serbia will be responsible for issuing certificates on compliance with conditions for performing utility services, to public enterprises, companies, entrepreneurs or other business entities. According to the Commission's opinion, this regulation would have presented an additional barrier to the entrance of new, as well as to the continuation of business operations of current market enterprises that are registered for providing utility services. In the final version of the Draft Law, the Ministry also included the Commission's suggestions that certain services that can be performed independently and are related to the utility services, be clearly defined as the commercial services (e.g. burial service) that can be provided by registered enterprises, under equal conditions, and not exclusively by public companies or companies in which the Republic of Serbia or local authorities owns a minimum $51 \%$ stakes. ${ }^{10}$ In the Commission's view, the Ministry's willingness to fully cooperate is the best example of joint efforts directed toward better quality regulation, which will enable more efficient market competition. ${ }^{11}$

\footnotetext{
${ }^{8}$ See Opinion and press release dated 23 May 2016, available at http://www.kzk.gov.rs/komisijauputila-misljenje-na-nacrt-zakona-o-izmenama-i-dopunama-zakona-o-komunalnim-delatnostima, last visited 14 August, 2017.

${ }^{9}$ See press release "Commission expressed concern about the proposed amendments to the Law on Public Utilities", dated 2 December 2015, available at http://www.kzk.gov.rs/en/komisija-izrazilazabrinutost-povodom-predlozenih-izmena-zakona-o-komunalnim-delatnostima, last visited 14 August, 2017.

${ }^{10}$ See press release "The Ministry Accepted Comments and Suggestions of the Commission on the Draft Law on Amendments to the Law on Utility Services", dated 24 July 2016, available at http:// www.kzk.gov.rs/en/ministarstvo-usvojilo-primedbe-i-pre, last visited 14 August, 2017.

${ }^{11}$ In the 2016-2017 Competition Advocacy Contest, organised by the International Competition Network and the World Bank Group, the Commission received the Honourable Mention for the report on the implementation of competition advocacy regarding the adoption of the Law on Amendments to the Law on Public Utilities. The Commission's entry is presented in the category "Implementing advocacy strategies at multiple levels (regional, national, subnational, economy
} 
The Commission reviewed the proposal of the Law on Investments, on its own initiative and issued an opinion which was delivered directly to the competent committee of the National Assembly. The Commission expressed concern about the proposed amendments to the Law on Investments, pointing out the possibility that the Commission could be prevented from carrying out its duties which could indirectly have a negative effect on investors in the Serbian market, as well as affect the protection of competition and the legal security of all investors. The National Assembly accepted the Commission's proposal that provided exemption for the Commission from the rules on priority treatment of applications from investors by public authorities. The Commission was again satisfied with the cooperation with the Ministry of Economy and National Assembly. ${ }^{12}$

By initiative of a third party, a company that provides beer-canning services, the Commission successfully influenced the Serbian Ministry of Agriculture, Forestry and Water Management to change, at the Commission's request, the provision of the Draft Law on Beer, which could have been restrictive in terms of competition. The restrictive provision stated that the filling of original packaging in the case of beer imported in bulk, as well as the service charge for the original packaging, can only be done by the producer. ${ }^{13}$ The amended rules provided that canning of such beer could be carried out both by producers and enterprises providing beer-canning services.

\subsection{Advocacy with Local Authorities}

Promoting effective competition throughout the country is also difficult task for the Commission because achieving this aim requires it to encourage negotiations at the local, i.e. municipal level and to ensure additional political support and knowledge of competition principles.

Furthermore, economic reforms in Serbia, like in other developing and transition countries, result in ownership of communal service facilities by local governments which cause a conflict of interest in this situation. Since the local authorities are the owners of these assets, they are interested in the profitability of its business, which can be enhanced by increasing prices and lowering of quality of services (Shyam Khemani et al. 1999). Under the competition law, the competition authority cannot legally intervene against local authorities and the competition advocacy is thus the only tool that can be used to change such anticompetitive practices.

wide and sector specific)". See http://www.worldbank.org/en/events/2016/10/24/the-2016---2017competition-advocacy-contest\#4, last visited 14 August, 2017.

${ }^{12}$ See Opinion and press releases date 19 October 2015 available at http://www.kzk.gov.rs/ komisija-uputila-misljenjena-predlog-zakona-o-ulaganjima, and dated 23 October 2015 available at http://www.kzk.gov.rs/usvojeno-misljenje-komisije, last visited 14 August, 2017.

${ }^{13}$ See Press Release available at http://www.kzk.gov.rs/kzk/wp-content/uploads/2016/06/ Misljenje-na-clan-9-Predloga-Zakona-o-pivu.pdf, last visited 14 August, 2017. 
The Commission nonetheless succeeded in influencing some local authorities to change their policies on providing utility services of burial and cemetery management. Following analysis of the initiative for investigation of possible competition infringement, the Commission sent opinions to the City of Novi Sad and City of Pančevo assemblies on the necessity to amend provisions of the decision regulating burial and cemetery management utility services, in order not to distort competition and provide monopolies for the public utility companies in those cities.

The City of Novi Sad and City of Pančevo assemblies positively reacted and informed the Commission that they had drafted amendment to modify the provisions of the disputed decisions regulating public utility burials and cemetery management services, and would adopt the amendments. ${ }^{14}$

The Commission also sent an opinion to the City of Subotica Assembly regarding a similar issue, where the Commission's position has not been acknowledged nor fully implemented. The Commission expressed its concern due to the City of Subotica Assembly failure to fully act on the Commission's opinion pertaining the disputed provisions of the decision regulating burial and cemetery management utility services in Subotica. Likewise, the Commission also sent an opinion to the line ministry pointing out the need to precisely define the terms of organise the area of burial and cemetery management in future regulations so as to avoid the monopolization of those activities based on different interpretations of the legal stipulations. ${ }^{15}$ The reactions of the City of Subotica and the Ministry, as well as the results of these advocacy activities, are still unknown.

Although the Commission was not provided enough political support, nor gained the understanding of the competent authorities, which is the most probable cause of its failure to achieve the advocacy goal, it again took the opportunity to emphasise the significance of the conduct of local authorities.

\subsection{Market Studies}

As a common component of the work portfolios of competition authorities, market studies serve two primary purposes: as a prelude or precursor to litigation and as a spearhead or foundation for competition advocacy (OECD 2008). Market studies are typically an instrument for competition advocacy, particularly used when there is no suspicion of violation of competition laws, yet it does not appear that the market is really working well, mostly because of public restrictions on competition. As a

\footnotetext{
${ }^{14}$ See press releases available at http://www.kzk.gov.rs/en/grad-novi-sad-obavestio-komisiju-da-jespreman-da-izmenom-odredbi-odluke-koja-ureduje-komunalnu-delatnost-sahranjivanja-iupravljanja-grobljima-omoguci-obavljanje-pojedinih-pogrebnih-usluga-svim-zaint and http:// www.kzk.gov.rs/en/grad-pancevo-ce-izmenom-propisa-omoguciti-obavljanje-pogrebnih-uslugasvim-zainteresovanim-ucesnicima, last visited 14 August, 2017.

${ }^{15}$ See Press Release available at http://www.kzk.gov.rs/en/skupstina-grada-subotice-nije-u-potpu, last visited 14 August, 2017.
} 
result, market studies may lead to proposals to deregulate, decrease barriers to entry, reform market institutions, or improve information dissemination to consumers or suppliers (OECD 2008).

Although the market studies can be costly and time consuming for a competition authority, they need to be used by competition authorities in order to: identify the causes of competition problems in a market-whether structural, government imposed or other; design more effective solutions to remedy a competition problem that can be implemented by government; and provide concrete market information to substantiate claims and recommendations made by a competition authority when engaging in advocacy efforts towards other government entities (OECD 2010).

In conclusion, market studies provide the competition authority with an in-depth understanding of the functioning of the market and its structures (number of players, barriers to entry, substitute markets, etc.). Therefore, it helps carry out more effective advocacy activities, especially when they are carried out in conjunction with regulators and through public consultations.

The Commission also uses market studies as an advocacy tool, with the clear objective of carrying out an effective advocacy program, pursuant to the Law on Protection of Competition. The Commission is authorised to monitor and analyse conditions of competition in individual markets and in individual sectors, as well as to analyse the state of competition in a particular sector of the economy or certain categories of agreements in various industries (sectoral analysis) in cases where the price dynamics or other circumstances suggest the possibility of restriction or distortion of competition. ${ }^{16}$

In 2016, the Commission conducted the Sector Inquiry on Competition Issues in Aftermarkets, based on the decision of the Commission's Council. The inquiry encompassed, inter alia, after sales services, warranties, turnover, and use of spare parts for motor vehicles and top selling home appliances - refrigerators and washing machines. The main goal of this inquiry was to establish the structure and relations between undertakings, their market shares and market power, with the objective of detecting potential market vulnerabilities, that is, existence of conditions leading to the infringement of competition. The added aim of this inquiry, and in particular of its conclusions and recommendations, is to point the competent government institutions to the conditions of the examined markets, while facilitating the proactive operation of the Commission aimed at deterring undertakings from competition infringement related conduct. ${ }^{17}$

The project was conducted in cooperation with the Public Policy Secretariat of the Republic of Serbia, with financial and technical support from the PERFORM Project, i.e. the Swiss Agency for Development and Cooperation. As per the project's ToR, prepared by the Commission, as the contracting authority of the inquiry,

\footnotetext{
${ }^{16}$ See the Law on Protection of Competition, Art. 21. and 47.

${ }^{17}$ See press releases date 15 November 2016, available at http://www.kzk.gov.rs/en/sektorskaanaliza-trzista-postprodajnih-usluga, and dated 9 June 2017, available at http://www.kzk.gov.rs/ en/komisija-upozorila-na-moguce-nekonku, last visited 14 August, 2017.
} 
the study was conducted by the Institute of Economic Sciences, as the research partner on the project. After the Sector Inquiry, all undertakings and others in the expert community were invited to submit their comments in accordance with the Report.

The results of the inquiry will be used in the course of preparing the draft regulation on conditions for group exemption of agreements in the motor vehicle sector, transporting the EU Commission Regulation 461/2010 into Serbian legislative system. The Commission is recommended to initiate the procedure of adopting such regulation.

The Commission is also recommended to consider revision of Regulation on Agreements between Undertakings Operating at Different Levels of Production or Distribution Chain Exempted from Prohibition, in order to harmonise the Regulation with EU Commission Regulation 330/2010 on categories of vertical agreements and concerted practices.

The Ministry of Construction, Transport and Infrastructure of the Republic of Serbia is recommended to initiate the adoption of a legal act, adopting EU rules on the obligation of producers of motor vehicles to communicate vehicle repair and maintenance information.

The preparation of the recommended regulations and legal acts is still ongoing, hence it takes time to see the final results of such advocacy activities. The Commission, in the meanwhile, has been intensively involved in additional reviewing of this document, in the context of the existence of potential competition infringements by undertakings operating in these sectors. The Commission formulated the findings and forwarded them to the competent state authorities, business associations, as well as undertakings operating in the motor vehicles and home appliances aftermarkets, in order to notify them of the possibility that they may become the subject of the Commission's proceedings in the event that they failing to amend certain portions of the agreements with their suppliers or dealers.

\subsection{Cooperation with Sector Regulators}

In the coming years, as the sector regulators in Serbia also become experienced in regulating the relevant markets, the success of competition advocacy could depend on the Commission's cooperation with regulators. The Commission should more actively influence regulators to create a competitive environment in the regulated markets, particularly in markets such as telecommunication and energy.

The Commission constantly undertakes activities to ensure continuous dialogue and provide an information exchange system with regulators and other state authorities in order to develop competition in the market. This cooperation with the regulators is covered by signed protocols of cooperation during previous years (National Bank of Serbia, Energy Agency of the Republic of Serbia, Regulatory Agency for Electronic Communications and Postal Services of the Republic of Serbia, Regulatory Authority for Electronic Media of the Republic of Serbia). It is, 
in Commission's view, assessed as useful, primarily in the case of data exchange, but also in exchanging opinions on all current topics and proceedings conducted before the Commission or other authorities and institutions. It provides the possibility to use market analyses and other studies and findings by regulators, to obtain new sources of information and new initiatives, exchange information, etc. ${ }^{18}$

Such cooperation, with the main aim of information exchange, could be an issue in achieving the objectives of the advocacy program in Serbia, because there is no open and active dialogue about anticompetitive measures, regulations and policies that are needlessly restricting competition in the market. Cooperation with sector regulators is two-way: the Commission requests data, in order to conduct proceedings and to carry out sectoral analyses of the markets or to act on received initiatives and petitions; and the Commission also acts on requests for opinions, data, information, etc. Even the Commission's opinions on regulators' reports are provided with the aim of determining compliance of these reports with competition rules. Moreover, this cooperation needs to be improved because it appears that comments to regulators tend to have greater success than those to state legislators (Cooper et al. 2005). Even closer cooperation should be established with regulators, but with substantial advocacy objectives.

\subsection{Building Public Awareness of Competition Policy}

In the context of using different tools for implementing competition advocacy activities with regard to the different groups of stakeholders, it is also important to create public awareness about competition law and explain the benefits of open competitive markets to the public (Sofia Competition Forum).

The Serbian Commission conducts advocacy activities also through select communication means (seminars, working groups, business meetings, articles in magazines), through the media (e.g. radio and TV broadcasts, newsletters, electronic media), publication of guidelines and reports, on its website, and other toolsvideo, social networks, etc.

Guidelines and reports are published on-line, such as the Annual Report of Commission (in which there is a part devoted to competition advocacy activities) and the Commission's opinions on drafts and current regulations affecting competition in the market. ${ }^{19}$ All decisions enacted by the Commission in the proceedings instituted on submitted notifications or ex officio, are also available to experts and the general public, via the website.

\footnotetext{
${ }^{18}$ See Annual Reports of the Commission.

${ }^{19} \mathrm{See}$ http://www.kzk.gov.rs/misljenja-na-predloge-propisa-i-na-vazece-propise-koji-imaju-uticajna-konkurenciju-na-trzistu, last visited 14 August, 2017.
} 
In addition to the Commission's website, some videos are uploaded to the YouTube.com website, which is interesting, considering that is an advocacy activity. These short films are about competition law awareness. ${ }^{20}$

The Commission published a booklet/glossary Essential for Competition, which contains explanations of the most frequent Serbian-English terms related to competition policy. During the preparation, particular attention was placed on the design and visual identity of the booklet so that the material would be attractive to the widest audience. The glossary is primarily designed for the media, the general public, as well as the expert audience. Over 400 copies were distributed to all news editors and journalists from electronic and print media outlets, public authorities, independent regulatory and supervisory agencies and most influential business associations. A particular goal of the publication is to establish a cooperative communication channel and improve levels of information dissemination. ${ }^{21}$

\section{Lessons Learnt}

Bearing in mind the Serbian experience, it can be concluded that competition advocacy is a complex and difficult task for competition authorities and outright success is relatively rare. Constant and continuing efforts are necessary because competition authorities will always be in a position to seek political support and at the same time be under the pressures from the private sector. The role of competition advocacy thus appears to be especially critical in developing countries, such as Serbia, because of their ongoing market and economic policy changes. Its fundamental role in such transition processes is very challenging for the Commission, as a relatively new competition authority, because it has to acquire the influence and skills necessary for this purpose.

The Serbian experience provides examples of competition advocacy work from which developing and transition countries could learn valuable lessons, in order to better understand how competition advocacy activities should be carried out and how competition authorities actually act.

Competition advocacy is a process that can mostly benefit from greater resources (both financial and human) and expertise, in order to enable the competition authority to provide high quality advice. In developing countries where resources will always be insufficient and unequally distributed, competition advocacy has somewhat limited value because limited resources limit the effectiveness of advocacy. Therefore, the most common pitfall of the competition work of young competition authorities is not to have the right resources or not to allocate them effectively.

\footnotetext{
${ }^{20} \mathrm{See} \quad$ https://www.youtube.com/channel/UC4r4DQ1UM8t339x9EaGCl_w, last visited 14 August, 2017.

${ }^{21}$ See http://www.kzk.gov.rs/en/medunarodne-i-domace-aktivnosti/domaca-saradnja, last visited 14 August, 2017.
} 
Competition authorities do not effectively allocate their resources mostly because advocacy is not enforcement and politicians thus do not pay attention to such work, although it is legitimate effort against anticompetitive harms. Furthermore, competition authorities are constrained because of the potential political backlash (Sokol 2009).

It is also important to point out that young competition authorities need to recruit and retain high quality staff and, if possible, create a special advocacy team that would be in charge of carrying out competition advocacy activities. It is recommended to simultaneously train the team and consult international organizations or engage external experts to scrutinise specific activities, which would be crucial for the competition authority to demonstrate an in-depth understanding of its competencies. Providing such an advocacy team with the power to undertake advocacy activities at their own initiative can be helpful in increasing the engagement of the competition authorities in the "promotion of a competitive environment". It should perform continuous research of drafts and existing laws and, for that purpose, use Internet, databases, journals, ministries and state agencies, non-governmental organisations, international organisations and companies, and also at the request of relevant state authorities, because the competition authority cannot be isolated or uninformed.

The competition authorities also need to gain credibility as an effective and impartial advocate for competition, because it is important to provide political support and understanding throughout the public and private sectors. Additionally, the competition authority should conduct competition advocacy activities in an open, transparent manner in order to safeguard its integrity and credibility, and free of political influence.

Its reputation must build relationships with government and ministries, and sector regulators, which must also be developed, and should extend to create public awareness of competition policy. Communication with different groups of stakeholders thus must be based on mutual respect, recognition of professional expertise and appreciation of the respective responsibilities (Shyam Khemani et al. 1999). At the same time, competition authorities need not be confrontational, since opposition to other state authorities could be risky, difficult and counterproductive (Shyam Khemani et al. 1999).

Further, it is important for the competition authority to continue the process of building suitable competition cultures, because most developing countries lack such awareness of the benefits of competition law and its effects. Building public awareness of competition policy can be achieved by using a variety of communication channels, but it is especially important to maintain face-to-face communication despite it being more resource consuming. Additionally, in order to explain the role of competition policy and competitive environment, the competition authorities need to establish good media relations (Shyam Khemani et al. 1999), which was crucial for the Serbian Commission in case of adopting of the Law on the Amendments to the Law on Public Utilities.

The competition authorities should include criteria for selecting and prioritising advocacy activities in order to identify proposed or existing policies (sector) that 
may restrict competition and carry out their competition assessment, such as economic importance of the policy, barriers to entry and the existence of public interest. Nonetheless, they should focus on competition matters that have the greatest impact on consumers, that are economically important, politically visible, that will not occupy too many resources, and in which the competition authority has a reasonable chance of success (Clark 2005).

Developing and transition countries should consider introduction a system requiring all state authorities to assess the impact on competition of legislative acts that they propose, since competition advocacy is not legally binding and policy-makers are not legally required to adopt the competition authority's opinions. Moreover, competition authorities should be allowed to offer their opinion on secondary legislation or legislation at regional and local level, as well as at the legislation on national government level.

It is also recommended to adopt explicit rules (e.g. provisions in the law, rules of procedure) on the relationship between the competition authority and the sector regulators, to ensure that the competition authority's opinions are provided in the early stages of legislative reform, i.e. before the legislative is adopted, as well as provisions on mandatory publishing of such opinions. Such ex ante competition assessment of laws and regulations would be in line with comparative best practices and state authorities should be required to state their reasons in case of noncompliance with competition authority's opinions.

Also, in the process of transition, developing and transition countries tend to promote policies aimed at protecting or supporting competitors rather than promoting competition itself. Moreover, young competition authorities should follow practices that include a pro-active approach to competition advocacy whereby opinions are issued not only to eliminate unnecessary restraints, i.e. anticompetitive practice, but also to influence the state authorities to liberalise and open the market to competition. They should act affirmatively and try to change rules because it is procompetitive to do so and it is good for competition. In that way, the competition authorities could at the same time achieve direct influence on government policies and policy proposals as an intermediate step towards achieving broader consumer and market benefits.

However, competition authorities should bear in mind one important limit to the benefits that providing opinions can yield: the competition authority is not a legislator and it only provides legislators and sector regulators with information concerning likely anticompetitive rules.

It is further recommended that competition authorities both enforce and advocate competition law in order to effectively complement and reinforce each other. Competition enforcement and advocacy are complementary and competition authorities should not identify these tasks or mutually substitute them, although competition advocacy is a more cost-effective means than enforcement, compared to fighting state-imposed barriers to competition. Competition advocacy should not replace enforcement even in part, and vice versa-the full implementation of competition rules and their enforcement cannot be achieved without successful advocacy. In many ways these activities are interdependent and complementary, and only a 
competition authority with both functions can be described as being consistently pro-competition.

In the context of the cooperation with sector regulators, it should be pointed out that sector regulators could at times avoid such cooperation with competition authorities because of the absence of rules on competition authorities' participating in the legislative process. This problem could be resolved simply through the introduction of an institutional measure (a statutory basis for regulatory intervention) but the question remains whether such rules would effectively be applied in practice, and whether competition authorities would come into conflict with certain regulators, due to the legacy of sector-specific policies. The efficacy of advocacy again will be dependent on the ability of the competition authority to provide direct political support for its activities and for establishing a proper relationship with these state authorities.

In this respect, the competition authorities could initiate cooperation with sector regulators, but it would be auspicious if sector regulators also would initiate cooperation, bearing in mind that advocacy activities are more effective when they are carried out in conjunction with the relevant sector regulators and through public hearings or consultations.

Therefore, it is so important to continue the practice of using market studies to improve in-depth understanding of the functioning of the specific sector and its market.

Finally, it should be noted that it is difficult to make the promotion of competition policy consistent due to the fact that competition advocacy faces a number of challenges and changes caused by political and economic developments. Competition advocacy is therefore controversial and not as straightforward. The nature of the competition advocacy of young authorities has changed over time, as in case of Serbia, shifting from advocating general competition issues and increasing public awareness of the benefits of competition, towards playing an increasingly important role in special sector industries.

The Commission followed the same direction, since during its formative stage advocacy activities were used to inform stakeholders of the existence of the competition law and policy and to provide opinions in the domain of privatisation. As time passed, advocacy evolved further, towards carrying out activities related to sector regulation and other policies, and being more active in competition advocacy and strengthening its role in building public confidence in competitive markets.

It appears that the Commission has became much more transparent, especially since 2015, exposed to publicity, open to competition advocacy activities and more aware of significance of competition advocacy, compared to the previous period when such practice was undeveloped. Based on the available information of Commission's practice, it is apparent that it pays more attention to raising awareness of the importance of competition by carrying out numerous activities aimed at advancing the regulatory framework, promoting competition policy and a competitive business environment.

For example, the Commission was particularly active in presenting the business and expert public communities in Serbia with all the aspects of its operations, 
derived from the competences vested in the Commission by the Law. In that sense, the Commission dedicated 2016, which also marked a decade of its operation, to implementing numerous competition policy advocacy activities. The Commission took part in many more conferences, as well as events organised by different associations, and it also organised and hosted several events that represented a basis for communicating with representatives of the media, aimed at promoting its activities. Among these, important to mention are the Competition Day, celebrating 10 years of operations in Serbia, and international conference Institution Building of the Competition Authorities in the South-East Europe.

Furthermore, the Commission carried out additional sector inquires (Sector Inquiry on Competition Issues in Aftermarkets and Insurance Market Competition Inquiry), in addition to annual inquires on the milk and oil-derivative industries. Moreover, it has been announced that Commission will carry out a retail market sector inquiry, which was the reason for holding the roundtable titled Significance and Challenges of the Retail Trade Sector in Serbia in Terms of Competition Policy.

Communication with the media during 2016 was intensified by utilising various communication channels (press releases, interviews, thematic events, conferences, Q\&As, promoting topics and public statements in the media, preparation and distribution of booklets). As a first step in the strategic utilization of the media potentials as communication tools, activities aimed at creating a detailed database relevant for the media relations was initiated during 2016, particularly concerning those specialised in the field of economics, law, markets or specifically the area of the Commission's particular concern-competition.

The Commission also improved its website (including the English version) and started publishing opinions on draft and current regulations, related to competition in the market on a special page, as well as many more press releases on daily and annual activities. Such practice contributed to the considerable increase traffic on the official website, up $31 \%$ against the previous year. Consequently, domestic and international media interest in the Commission's activities has increased. Print and e-media journalists have sent a significant number of inquiries concerning the Commission's area of expertise. ${ }^{22}$

To conclude, young competition authorities should continue expanding their role in promoting competition and achievements in order to develop competition law and a competitive market. In this sense, Serbian competition advocacy could be regarded as a positive example for countries experiencing difficulties in promoting economic development during the economic transition process.

Serbian practice has been recognised as a successful example of competition advocacy in the community of developing countries and the business community in Serbia. As mentioned, competition advocacy in Serbia has received a positive evaluation internationally (in 2016-2017 Competition Advocacy Contest, organised by the International Competition Network and the World Bank Group).

\footnotetext{
${ }^{22}$ See http://www.kzk.gov.rs/en/medunarodne-i-domace-aktivnosti/domaca-saradnja, 14 August, 2017.
} 
Additionally, the traditional review of the business climate in Serbia (White Book), published by the Foreign Investors Council in Serbia, reports that significant improvements have been achieved to the Commission's advocacy activities. As per evaluation of the Foreign Investors Council, the progress in the field of protection of competition was propelled, among other, by the Commission's strong advocacy activities.

In the opinion of Foreign Investors Council, an extremely positive development is the public invitation that the Commission sent to all relevant stakeholders, to submit comments to the draft Regulation on Notification of Concentration, whose revision it has initiated. ${ }^{23}$

The advocacy program in Serbia originated from the rigorous enforcement programs in Serbia, although Serbia lacked a competition culture and expertise in competitive analysis, as is the case in most developing countries. With the straightforward aim to promote competition, the Commission engaged in competition advocacy despite the facts that it was a new state authority with limited resources, without highly trained staff, expertise, empirical evidence on how advocacy actually works, reputation, or culture of competition on which to rely.

Serbia did not have a political culture that fully embraced competition and the free market, nor the political and legal institutions that provide greater protection for contract and property rights (including efficient courts and independent media), which made this success even greater. For these reasons, the Commission may be sometimes reluctant to seek legislative changes because it may fear that its powers may be eroded when competition matters come before the legislature. Moreover, it seems that during legislative procedures the Commission's opinions are not sufficiently appreciated in practice. Still, numerous rules have been adopted based on the Commission's opinions.

Hence, the effectiveness of competition advocacy depends not only on the strength and characteristics of the competition authority, but also on the framework within which it operates. Consequently, the Commission could carry out a more systematic approach to competition advocacy and engage more actively in such activities in order to successful implement advocacy program.

\section{Conclusion}

The overview in this article presents how the Serbian Commission is promoting competition and a competitive environment for economic activities. In this regard, competition advocacy should probably become the "essential facility" for the competitiveness of the Serbian market, because the Commission should play an

\footnotetext{
${ }^{23}$ See press release http://www.kzk.gov.rs/en/komisija-znacajno-napredovala-ocen, http://www. kzk.gov.rs/en/komisija-ucinila-znacajan-pomak-u-svom-radu-po-oceni-saveta-stranih-investitora, 14 August, 2017.
} 
important role in reducing government restraints on competition. The main goal of the advocacy program needs to be the elimination of barriers to competition and barriers to entry into the market, and otherwise minimising unnecessary government intervention in the market, which is considered to be the greatest threat to competition in the Serbian market.

Competition advocacy is still a real challenge in Serbia and it takes time for the Commission to become effective in these activities. The level of success of the advocacy program in Serbia appears to still rely on the extent of the political support enjoyed by the Commission. Moreover, the Commission advocacy activities are not fully recognised by policy makers and it needs to acquire more credibility and resources, as an effective and impartial advocate for competition. The Commission must therefore give ongoing attention to building a competition culture through aggressive public relations and dissemination of information.

Finally, the Commission should collect data on competition advocacy "success" and consider the first results of advocacy program. Since there is no systematic evidence on implementation experience or formal attempts to assess the effectiveness of competition advocacy in Serbia; the collected data would be a basis for such evaluation. The Commission should consider carrying out this evaluation because it is a way to determine what types of advocacy activities are most effective, and in which sectors. ${ }^{24}$

For these reasons, competition advocacy in Serbia should be more actively engaged in order to fully promote the competitive market, and consequently protection of competition and consumer welfare.

\section{References}

Begović B et al. (2003) New competition policy: a policy paper. Center for Liberal-Democratic Studies, Belgrade

Carpagnano M (2016) The effects of competition advocacy on the pro-competitive regulation of the markets. Ital Antitrust Rev 1:109-113

Clark J (2005) Competition advocacy: challenges for developing countries. OECD J Compet Law Policy 6:69-80

Commission for Protection of Competition (2012) Annual report for 2011. http://www.kzk.gov.rs/ kzk/wp-content/uploads/2012/08/Annual-Report_2011.pdf

Cooper JC, Pautler PA, Zywicki TJ (2005) Theory and practice of competition advocacy at the FTC. Antitrust Law J 72:1091-1112

\footnotetext{
${ }^{24}$ It has been pointed out that the evaluation of competition advocacy is important for several reasons: competition authorities are accountable to representatives for their use of state resources and the powers entrusted to them, and the latter may want evidence of the effectiveness of the former's activities; competition authorities want to know what best practices can be established for competition advocacy; competition authorities have to decide how to allocate scarce budgetary resources, personnel time, media exposure, and other inputs across the enforcement and advocacy functions; competition authorities may want to establish priorities over the different types of competition advocacy that they can perform (Evenett 2006).
} 
Dabbah MM (2010) International and comparative competition law. Cambridge University Press, New York

Evenett SJ (2006) Competition advocacy: time for a rethink. Northwest J Int Law Bus 26:495-514

International Competition Network (2002) Advocacy and competition policy: report prepared by the Advocacy working group. ICN's conference Naples, Italy. http://www.international competitionnetwork.org/uploads/library/doc358.pdf

International Competition Network (2004, April) Competition advocacy in regulated sectors: examples of success. http://www.internationalcompetitionnetwork.org/uploads/library/doc370. pdf

Kovacic W (1997) Getting started: creating new competition policy institutions in transition economies. Brooklyn J Int Law 23:403-453

Law on Protection of Competition. Official gazette of the RS 51/2009, 95/2013

OECD (2008) Market studies - competition policy roundtables 2008. DAF/COMP (2008) 34. http://www.oecd.org/regreform/sectors/41721965.pdf

OECD (2010) Strategies for competition advocacy: background paper by the OECD secretariat. Latin American competition forum - session III: strategies for competition advocacy. DAF/COMP/LACF (2010) 4. http://www.oecd.org/competition/latinamerica/2010LACF-Strat egies-for-competition-advocacy.pdf

Popovic D (2013) Competition law enforcement in times of crisis: the case of Serbia. Yearb Antitrust Reg Stud 6:35-51

Rakić I (2009) Control of concentrations in the Republic of Serbia. In: Milošević M (ed) Serbian law in transition. Institute of Comparative Law, Belgrade, pp 101-128

Rakić I (2012) Utvrđivanje relevantnog tržišta - osvrt na zabludu iz slučaja Cellophane. Anali Pravnog fakulteta u Beogradu 60:416-430

Rakić I (2014) Pokajnički program i odgovornost za štetu zbog povrede prava konkurencije. Anali Pravnog fakulteta u Beogradu 62:244-260

Rebecchini S (2014) Competition advocacy: the Italian experience. Ital Antitrust Rev 2:13-24

Rodriguez AE, Coate MB (1997) Competition policy in transition economies. The role of competition advocacy. Brooklyn J Int Law 23:367-401

Shyam Khemani R, Clark J, Fornalczy A (1999) Competition advocacy. In: Shyam Khemani R (ed) A framework for the design and implementation of competition law and policy. World Bank/OECD, Washington, DC/Paris, pp 93-100

Sofia Competition Forum. Guidelines for implementing competition advocacy, Bulgarian Commission on Protection of Competition/United Nations Conference on Trade and Development. http://unctad.org/meetings/en/Contribution/ccpb_SCF_AdvocacyGuidelines_en.pdf

Sokol DD (2009) Limiting anticompetitive government interventions that benefit special interests. Georg Mason Law Rev 17:119-189

Stucke ME (2008) Better competition advocacy. St Johns Law Rev 82:951-1036

Open Access This chapter is licensed under the terms of the Creative Commons Attribution 4.0 International License (http://creativecommons.org/licenses/by/4.0/), which permits use, sharing, adaptation, distribution and reproduction in any medium or format, as long as you give appropriate credit to the original author(s) and the source, provide a link to the Creative Commons license and indicate if changes were made.

The images or other third party material in this chapter are included in the chapter's Creative Commons license, unless indicated otherwise in a credit line to the material. If material is not included in the chapter's Creative Commons license and your intended use is not permitted by statutory regulation or exceeds the permitted use, you will need to obtain permission directly from the copyright holder.

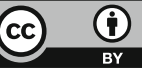

